Agata Łopatkiewicz*

Kraków

\title{
Wątki liberal education w filozofii anarchizmu metodologicznego Paula K. Feyerabenda
}

Celem artykułu jest analiza koncepcji filozoficznej Paula K. Feyerabenda pod kątem zgodności z podstawowymi wyznacznikami koncepcji liberal education. Rozważania skoncentrowane są wokół próby odpowiedzi na pytanie, czy w filozofii anarchizmu metodologicznego odnaleźć można wątki charakterystyczne dla anglosaskiej wykładni kategorii edukacji liberalnej' Analizę otwiera skrótowa prezentacja filozoficznych poglądów Feyerabenda, obejmująca w szczególności ustalenia dotyczące roli i miejsca nauki pośród innych sposobów osiągania wiedzy, ideę pluralizmu epistemologicznego oraz warunki możliwości przyjęcia humanistycznej perspektywy poznawczej. W dalszej kolejności objaśnienia wymaga koncepcja liberal education wraz ze wskazaniem na jej przedmiotowy i podmiotowy aspekt. Charakterystyka wskazanych zagadnień daje asumpt do analizy problemu tytułowego. Rozważania zamyka wskazanie zagadnień wymagających dal-

* Mgr Agata Łopatkiewicz jest doktorantką w Instytucie Pedagogiki Uniwersytetu Jagiellońskiego w Krakowie.

${ }^{1}$ Celem uprzystępnienia prowadzonego wywodu, pojęcia liberal education oraz edukacja liberalna uznać należy za synonimiczne. Na temat językowej wykładni kategorii liberal education zob. K. Wrońska, Liberal Education in Selected Polish Pedagogical Concepts - in Comparison to English-language Concepts - with Particular Reference to the Enlightenment (Period 2), „Kultura i Wychowanie” 6 (2013), s. 9-20. 
szego opracowania oraz próba odpowiedzi na pytanie o związki anarchizmu metodologicznego z koncepcją liberal education.

\section{Filozofia anarchizmu metodologicznego Paula K. Feyerabenda}

Gdyby uporządkować filozoficzne stanowiska dotyczące nauki według kryterium ich przywiązania do uniwersalizmu nauki oraz uznania prymatu jej twierdzeń nad innymi formami poznania, stanowisko Feyerabenda ulokować należałoby na biegunie przeciwległym względem racjonalizmu metodologicznego w nauce. Filozofia ta zdaje się popadać w sprzeczność z perspektywą myślenia o nauce zapoczątkowaną w starożytności i kontynuowaną, z niewielkimi modyfikacjami, do dnia dzisiejszego. Ideę przewodnią, porządkującą poglądy myśliciela skoncentrowane wokół zagadnień z zakresu filozofii i metodologii nauki, stanowi, z jednej strony, teza o różnorodności sposobów osiągania wiedzy o rzeczywistości zewnętrznej, z drugiej zaś, przekonanie o braku uzasadnionego uprzywilejowania działalności naukowej przed innymi formami poznania. Negatywna odpowiedź na pytanie o prawomocność nauki w połączeniu z przeświadczeniem o konieczności przezwyciężenia instytucjonalnego oporu przedstawicieli działalności badawczej doprowadziły Feyerabenda do przyjęcia stanowiska anarchizmu metodologicznego ${ }^{2}$. Niewspółmierność, a nierzadko sprzeczność twierdzeń opisujących wybrane aspekty rzeczywistości zewnętrznej świadczy, zdaniem filozofa, o fałszywości przekonania o racjonalności działalności badawczej. Skoro ponadhistoryczna metodologia zawodzi, dopuszczalne stają się wszelkie sposoby poznania, $\mathrm{w}$ tym również nienaukowe. Zgodnie $\mathrm{z}$ regułą anything goes $^{3}, \mathrm{z}$ myślenia o nauce i wtórnie procesu badania rzeczywistości

${ }^{2}$ Z uwagi na niedostatek polskich tłumaczeń dzieł Feyerabenda, jak również wysoki stopień ekstrawagancji prezentowanych przez niego tez, anarchizm metodologiczny często utożsamiany jest $\mathrm{z}$ anarchizmem naiwnym, w sposób bezrefleksyjny i niezasadny negującym wszelką wartość poznania naukowego. Pogląd taki uznać należy za upraszczający, a ponadto istotnie zniekształcający faktyczne przekonania filozofa. Zob. K. Zamiara, Od redakcji, w: P. K. Feyerabend, Przeciw metodzie, Wrocław 2001, s. 5.

${ }^{3}$ Podkreślenia wymaga wielość przekładów maksymy anything goes. Co szczególnie interesujące, dostępne tłumaczenia - wszystko ujdzie, wszystko wolno, wszystko przejdzie, rób, co chcesz - w dużym stopniu determinują postrzeganie systemu filozoficznego Feyerabenda w kategoriach anarchizmu naiwnego. Najbardziej neutralna, a przy tym wiernie oddająca intuicje filozofa wydaje się interpretacja autorstwa Stefana Wiertlewskiego, utożsamiająca angielskie brzmienie maksymy z tezą nic świętego. Zob. Tamże. 
wykluczyć należy bariery metodologiczne, które spowalniają proces twórczy, ograniczając tym samym szanse na osiągnięcie wartościowych poznawczo rezultatów ${ }^{4}$.

Zniesienie przez Feyerabenda ugruntowanego w myśli filozoficznej poglądu, zgodnie z którym pomiędzy nauką a innymi sposobami poznania rzeczywistości zewnętrznej istnieje zasadnicza różnica jakościowa, posiada doniosłe konsekwencje dla postrzegania celu oraz zadań stawianych przed namysłem o charakterze naukowym. Pozbawiając naukę autorytetu, pluralizm epistemologiczny równa jej wartość z walorem płynącym z poznania metafizycznego, religijnego czy potocznego ${ }^{5}$. Zgodnie ze stanowiskiem filozofa, ,nauka nie jest świętością. Sam fakt, że istnieje, jest podziwiana i posiada osiągnięcia, to jeszcze za mało, żeby uczynić ją wzorcem doskonałości"6. Podobnie jak nienaukowe strategie poznania, sama nauka boryka się z problemem wewnętrznych sprzeczności, niedostatków metodologicznych czy niepotwierdzalnych hipotez. Feyerabend zauważa ponadto, że nauka, rozumiana jako zbiór twierdzeń uznanych i akceptowanych $\mathrm{w}$ danym czasie przez gremium badaczy określonej dyscypliny, pozostaje pod przemożnym wpływem czynników o charakterze politycznym i ekonomicznym ${ }^{7}$. Sytuacja taka w znacznej mierze ogranicza samoistny rozwój nauki; co więcej, prowadzi do utrwalania twierdzeń i osiągnięć użytecznych z punktu widzenia kryteriów niewyłącznie naukowych. W rezultacie bezrefleksyjna ufność w autorytet nauki jako jedynej pewnej formy gromadzenia wiedzy skutkuje jej postępującym uwikłaniem w sferę władzy ${ }^{8}$,

${ }^{4}$ G. Bachelard, Filozofia, która mówi nie. Esej o filozofii nowego ducha w nauce, Gdańsk 2000, s. 16-17.

${ }_{5}^{5}$ Sam Feyerabend nie wyklucza sytuacji, w której uzasadnione będzie uznanie przejściowego prymatu racjonalności naukowej. Warunek ten wymaga jednak rzeczywistej przewagi nauki nad innymi strategiami poznania, nie zaś bezwiednego przypisania jej waloru dominacji. Zob. P. K. Feyerabend, Przeciw metodzie, s. 21.

${ }^{6}$ Tamże, s. 218.

7 Tamże, s. 12.

${ }^{8}$ We wskazanym aspekcie propozycja Feyerabenda zbliżona jest do koncepcji postulowanej przez Michela Foucault. Diagnoza utożsamiająca wiedzę z władzą trafnie oddaje postmodernistyczne intuicje dotyczące relatywizmu poznawczego oraz czasowej dominacji pewnych kompleksów twierdzeń o rzeczywistości zewnętrznej. Jak słusznie zauważa Foucault, w konkretnym czasie dyskursem rządzą określone reguły determinujące treść wypowiadanych sądów. Aksjomatyka systemu wiedzy precyzuje nie tylko przedmiotowy zakres samego dyskursu, ale również podstawowe ustalenia dotyczące prawdziwości i fałszywości twierdzeń, czy przepisy wykluczenia i opozycji. Zob. S. J. Ball, Foucault i edukacja. Dyscypliny $i$ wiedza, Kraków 1994, s. 187n. 
a ponadto pominięciem alternatywnych, potencjalnie wartościowych strategii poznania9.

Środka przeciwdziałającego nieuprawnionej dominacji zbioru twierdzeń naukowych, wyodrębnionych z uwagi na kryterium utylitarne, Feyerabend upatruje $\mathrm{w}$ metodologicznym otwarciu $\mathrm{w}$ ramach samej nauki, jak również w obrębie ludzkiego poznania w ogóle. Sprzeciw wobec epistemologicznych ograniczeń ${ }^{10}$, roszczenie o przywrócenie pełnej wolności w kwestii doboru problemów badawczych, strategii poznawczych i stosowanych metod oraz wspieranie nieskrępowanego, twórczego rozwoju każdego człowieka niezależnie od zainteresowań poznawczych stanowić ma skuteczną przeciwwagę wobec destrukcyjnej rozwojowo praktyki przypisywania nauce wyłącznej funkcji opisującej, objaśniającej oraz prognozującej.

\section{Elementy konstytutywne koncepcji liberal education}

Koncepcja liberal education ${ }^{11}$ stanowi niezwykle interesującą propozycję teoretycznego opracowania zagadnienia istoty, komponentów oraz celów kształcenia ${ }^{12}$ człowieka. $Z$ uwagi na szeroki zakres przedmiotowy wskazanej problematyki dostępne opracowania naukowe cechuje duża różnorodność przyjmowanych perspektyw oglądu. Jakkolwiek nie istnieje uniwersalna, zobiektywizowana wykładnia liberal education, możliwe wydaje się wskaza-

9 Rozumianego jako przyrost twierdzeń na temat rzeczywistości zewnętrznej w czasie, osiągany na podstawie niewyłącznie naukowych strategii poznania.

${ }^{10} \mathrm{~W}$ tym egzekwowanym przez samych naukowców standardom, kryteriom oraz wzorcom racjonalnej pracy badawczej.

${ }^{11} \mathrm{Z}$ uwagi na genezę anglosaską na gruncie rodzimej literatury przedmiotu próżno szukać opracowań podejmujących wątki edukacji liberalnej. Co więcej, polska pedagogika zdaje się pozostawać pod wpływem niemieckiej filozofii edukacji, o czym świadczy inspiracja nurtem postkantowskim czy filozofią kultury. Różnice pomiędzy anglosaskim i niemieckim podejściem do kwestii kształcenia zaznaczają się już w warstwie terminologicznej, związanej $\mathrm{z}$ funkcjonowaniem kategorii liberal education i Bildung. W zestawieniu z nurtem anglosaskim teorie niemieckie w znacznie większym stopniu skoncentrowane są na zagadnieniu partycypacji jednostki w ustrukturowanym układzie kulturowym, będącym podstawowym punktem odniesienia dla procesu kształcenia. Zob. Bildung, w: C. Winch, J. Gingell (red.), Philosophy of Education. The Key Concepts, London-New York 2008, s. 23n.

12 Dla jasności prowadzonych rozważań, pojęcia edukacji i kształcenia traktować należy jako synonimiczne. Jakkolwiek na gruncie szczegółowych zagadnień związanych z koncepcją liberal education na znaczeniu zyskują różnice cechujące wskazane kategorie, w generalnej, uproszczonej perspektywie uznać można ich tożsamość znaczeniową. 
nie elementów konstytutywnych tej kategorii. W drodze definicji negatywnej edukację liberalną odróżnić należy od innych terminów funkcjonujących na określenie ukierunkowanej działalności poznawczej człowieka, w szczególności edukacji zawodowej i obywatelskiej. Jakkolwiek koncepcja liberal education wydaje się pozostawać w związku z każdą ze wskazanych perspektyw, jej problematyka wykracza poza przygotowanie do wykonywania zawodu i nabywanie umiejętności przydatnych ze społecznego punktu widzenia.

W warstwie przedmiotowej, obejmującej elementy sine qua non edukacji liberalnej, ulokować należy kategorię wiedzy sensu largo, rozumianej nie tyle w odniesieniu do zbioru faktów, ile wykraczającej poza konkretną dyscyplinę nauki sprawności w gromadzeniu i przetwarzaniu informacji ${ }^{13}$. Kompetencja ta bazuje na generalnej zdolności do rozumienia ${ }^{14}$, obejmującej możność wartościowego, logicznego, empirycznego, moralnego czy estetycznego oglądu wybranych aspektów rzeczywistości zewnętrznej ${ }^{15}$. W rezultacie edukację liberalną zasadnie rozpatrywać można w kategoriach inicjacji pozwalającej na aktywną i, co szczególnie istotne, świadomą partycypację podmiotu $\mathrm{w}$ wartościach nauki, kultury i sztuki ${ }^{16}$. Podkreślenia wymaga, że warunkiem podjęcia działalności tego rodzaju jest wolność rozpatrywana $\mathrm{w}$ wymiarze pozytywnym jako możność wyboru elementów wartościowych i pożądanych z uwagi na rozwój jednostki oraz, w szerszej perspektywie, wspólnoty, której jest członkiem.

W wymiarze podmiotowym koncepcja liberal education skoncentrowana jest wokół człowieka odnajdującego satysfakcję w różnorodności działań, podejmowanych na rzecz własnego, systematycznego, dobrowolnego rozwoju ${ }^{17}$. Nieinstrumentalny, głęboko humanistyczny wymiar tego procesu wyraża się w orientacji na samodoskonalenie. Poza wymiarem intelektual-

13 Liberal education, w: C. Winch, J. Gingell (red.), dz. cyt., s. 122.

${ }^{14}$ Kategorię rozumienia analizować można z uwzględnieniem szczegółowych mechanizmów warunkujących proces kształcenia, takich jak zdolność do logicznego myślenia, umiejętność syntezy i analizy, problemowego wykorzystania informacji, poszukiwania związków pomiędzy sferą teorii i praktyk czy krytycznej analizy. Zob. P. H. Hirst, Knowledge and the curriculum. A collection of philosophical papers, London-Boston 1975, s. 38.

15 Tamże, s. 39.

${ }_{16}$ Zob. K. Wrońska, Liberal Education in Selected Polish Pedagogical Concepts - in Comparison to English-language Concepts - with Particular Reference to the Enlightenment (Period 1), „Kultura i Wychowanie” 5 (2013), s. 38.

${ }_{17}$ Realizacja celów praktycznych nie stanowi przy tym zasadniczej dyskwalifikacji, należy jednak pamiętać, że w opozycji do kształcenia zawodowego, edukacja liberalna przekracza wymiar czysto instrumentalny i obejmuje znacznie szerszy zbiór elementów aniżeli 
nym związanym z poznaniem naukowym, edukacja liberalna mieści komponent aksjologiczny, manifestujący się w podejmowaniu aktywności wartościowej i dobrej z uwagi na interes indywidualny i wspólnotowy. U podstaw idei liberal education zasadnie poszukiwać można wpływów starożytnej etyki, skoncentrowanej wokół pytania o dobro jako warunek pomyślnego życia. W rezultacie obok wiedzy czysto teoretycznej i praktycznej jako filar edukacji liberalnej wskazać należy wiedzę o dobru, będącą rodzajem troski o rozwój zgodny z greckim ideałem mądrości i szlachetności ${ }^{18}$.

Wyrażająca istotę edukacji liberalnej synteza poznania intelektualnego, krytycznego oglądu, umiejętności praktycznych oraz aksjologicznej orientacji na rozwój i osiąganie pomyślności stanowi przedsięwzięcie dalece bardziej perspektywiczne niż ma to miejsce w przypadku krótkoterminowych planów edukacyjnych sporządzanych w odniesieniu do kształcenia zawodowego. Poza realizacją zamysłów poznawczych, bezpośrednio związanych z przyrostem wiedzy o rzeczywistości zewnętrznej, edukację liberalną zasadnie uznać można za cel sam w sobie - rozwój umysłowy, estetyczny i moralny pozostaje bowiem w ścisłym związku z procesem samodoskonalenia. Edukacja sprzyja nabywaniu nowych doświadczeń, równocześnie pozwala je zrozumieć i włączyć w struktury już posiadanej wiedzy. Czas trwania tego procesu wydaje się ograniczony wyłącznie wolą podmiotu poznającego.

\section{Związki anarchizmu metodologicznego z koncepcją liberal education}

Przypuszczać można, że postulowana przez Feyerabenda filozofia anarchizmu, znosząc autorytet i pierwszeństwo nauki przed innymi formami poznania, uniemożliwia prowadzenie namysłu charakterystycznego dla $l i$ beral education. Należy przy tym zaznaczyć, że badacze rozwijający koncepcję edukacji liberalnej nie podejmują w sposób bezpośredni problematyki filozofii nauki. Nie wprost można domniemywać, że zamysł kształcenia sensu largo bazuje na założeniu o istnieniu różnicy jakościowej pomiędzy działalnością naukową, a innymi, pozanaukowymi formami aktywności poznawczej. Uzasadnienia dla tej tezy dostarcza wskazanie mechanizmów

wyłącznie wąsko wyspecjalizowaną wiedzę dotyczącą wybranych aspektów rzeczywistości zewnętrznej.

${ }_{18}$ P. Hirst, dz. cyt., s. 30n. 
warunkujących gromadzenie wiedzy, obejmujących zdolność logicznego myślenia, syntezy czy analizy, zaliczanych do strategii czysto naukowych, jak również przewodnia idea partycypacji jednostki w intelektualnym dorobku minionych pokoleń ${ }^{19}$. Pomimo pozornych różnic, cechujących filozofię anarchizmu metodologicznego i koncepcję liberal education $\mathrm{w}$ aspektach związanych z dobrowolnym, świadomym rozwojem, nabywaniem wiedzy, rolą nauki czy celami działalności poznawczej, na gruncie systemu Feyerabenda odnaleźć można elementy wskazujące na istnienie korelacji pomiędzy wskazanymi stanowiskami. Skojarzenia z anglosaskimi ideami liberal education nasuwa sam fakt wszechstronnego wykształcenia Feyerabenda, obejmującego fizykę, filozofię, matematykę, astronomię, a ponadto rozległe zainteresowania muzyczne i teatralne ${ }^{20}$. Jakkolwiek wnioskowanie o poglądach na podstawie biografii uznać należy za oczywiście zawodne, intuicja dotycząca związków anarchizmu filozoficznego z koncepcją edukacji liberalnej znajduje przynajmniej częściowe potwierdzenie na gruncie rozpraw naukowych Feyerabenda.

Mimo że jednym z podstawowych postulatów pluralizmu epistemologicznego jest zrównanie wartości działalności naukowej i alternatywnych form poznania, anarchizm nie pozbawia nauki należnego jej uznania. Podkreślenia wymaga, że Feyerabend rozróżnia przy tym co najmniej dwie interpretacje pojęcia nauki ${ }^{21}$. Zgodnie z pierwszą wykładnią, nauka stanowi określony, względnie domknięty zbiór twierdzeń, dotyczących rzeczywistości zewnętrznej, wyodrębnionych z uwagi na cel utylitarny ${ }^{22}$. W ujęciu takim nauka spełnia względem aparatu władzy rolę służebną, co więcej, pomimo przymiotów racjonalności i powszechnej ważności nadawanych przez środowisko badaczy, pod względem osiągnięć niewiele odbiega od strategii poznania pozbawionych fundamentu w postaci naukowych osiągnięć cywilizacji zachodniej ${ }^{23}$. Alternatywna wykładnia zakłada analizę wykraczającą poza

19 Poszerzenie perspektywy oglądu o poznanie moralne czy estetyczne nie wydaje się modyfikować ustalenia o nadrzędnej roli nauki względem alternatywnych form poznania.

${ }^{20}$ P. K. Feyerabend, Zabijanie czasu, Kraków 1996, s. 68n.

${ }^{21}$ Wskazane ujęcia odróżnia wartościujące podejście Feyerabenda - krytyczne w stosunku do wizji nauki zawężonej do zbioru tez lansowanych w środowisku badaczy i uprawianej na sposób instytucjonalny oraz konstruktywnej - w odniesieniu do nauki sensu largo, otwartej na wielogłos alternatywnych teorii i metod.

22 P. K. Feyerabend, Przeciw metodzie, s. 12; por. tenże, Jak być dobrym empirysta??, Warszawa 1979, s. 23n.

${ }^{23}$ Uwaga ta dotyczy w szczególności nauk przyrodniczych. W wielu przypadkach, zwłaszcza w odniesieniu do cywilizacji starożytnych, myśl niezwiązana ze współczesnymi 
lansowany w danym okresie model, obejmującą swoim zasięgiem działalność ukierunkowaną na rozwój i wzbogacanie życia, a nie wyłącznie generowanie wiedzy ${ }^{24}$. Nauka sensu largo pozostaje w ścisłym związku z historią i kulturą, aprobując poglądy odmienne, a nierzadko nawet sprzeczne ${ }^{25}$.

Koncepcja nauki leżąca u podstaw edukacji liberalnej pozostaje w związku z szeroką, zorientowaną na podmiot poznający interpretacją nauki. Rozwój intelektualny stanowi jeden z filarów liberal education. Zarazem elementem, który odróżnia edukację liberalną od zawodowej, wydaje się nieliniowy model nabywania wiedzy ${ }^{26}$, a ponadto uwzględnienie kontekstu historycznego i kulturowego, tworzącego tło dla rozważań czysto naukowych. Stanowisko takie podziela Feyerabend, wskazując na szkodę, jaką przynosi separacja twierdzeń nauki i ich kulturowego fundamentu ${ }^{27}$. Koncentracja na utylitarnej funkcji poznania naukowego, będąca pożądanym współcześnie celem kształcenia, radykalnie upraszcza funkcje przypisywane nauce. W rezultacie w perspektywie podmiotowej zubaża rozwój intelektualny, sprowadzając jego istotę do biernej recepcji faktów wyłączonych z kulturowej i historycznej płaszczyzny doświadczenia.

Uznanie tezy, na mocy której „dążenie do poszerzenia wolności, do prowadzenia życia pełnego i dającego zadowolenie, oraz korespondujące z nim usiłowanie odkrycia tajemnic natury i człowieka, pociąga $[\ldots]$ odrzucenie wszelkich uniwersalnych standardów i wszelkich sztywnych tradycji (naturalnie, pociąga to również odrzucenie dużej części współczesnej nauki)"28 prowadzi Feyerabenda do interesującej konstatacji, zgodnie z którą znakomita większość przełomowych odkryć naukowych dokonana została w wyniku intelektualnej niesubordynacji, nie zaś przetwarzania ugruntowanych twierdzeń. Innymi słowy, za warunek sine qua non możliwości uprawiania nauki uznać należy wolność do kwestionowania przekonań usankcjonowanych

kryteriami naukowości okazała się nieporównywalnie bardziej skuteczna w rozwiązywaniu problemów o charakterze empirycznym. Zob. P. K. Feyerabend, Przeciw metodzie, s. 12.

24 Tamże.

${ }^{25}$ W myśl zasady, zgodnie z którą anarchizm teoretyczny jest bliższy człowiekowi i w większym stopniu sprzyja postępowi niż koncepcje nauki akcentujące porządek i ład. Zob. tamże, s. 14.

${ }^{26}$ Wyrażający się w dobrowolnej, nieskrępowanej aktywności obejmującej treści przynależne do różnych dyscyplin naukowych.

27 Tamże, s. 19.

28 Tamże, s. 20. 
przez autorytet ludzi nauki ${ }^{29}$. Dobrowolne, swobodne i otwarte uczestnictwo w nauce stanowi element nieodzowny jej rozwoju. Anarchizm metodologiczny, jakkolwiek nieobojętny na kwestie związane z szeroko rozumianym kształceniem, nie posługuje się nomenklaturą właściwą dla koncepcji liberal education. Parafrazując stanowisko Feyerabenda, przyjąć można, że praktyczna realizacja idei edukacji liberalnej stanowi o rzeczywistym postępie w nauce. $\mathrm{Z}$ tego względu maksyma anything goes, rozumiana jako świadome odrzucenie tezy o nieomylności nauki ${ }^{30}$, stanowi nie tylko element konstytutywny stanowiska anarchistycznego, lecz także, przynajmniej w pewnym zakresie, cechuje anglosaski model edukacji w duchu liberalizmu.

W konsekwencji przyjęcia szerokiej wykładni pojęcia nauki oraz uznania anarchistycznie rozumianej wolności jako warunku osiągania wartościowych poznawczo rezultatów Feyerabend poddaje krytyce współczesny model kształcenia instytucjonalnego. Działalność szkół, w jego opinii, stanowi zasadniczą przeszkodę $\mathrm{w}$ edukacji $\mathrm{w}$ duchu humanistycznym ${ }^{31}$. Przyczyn takiego stanu rzeczy upatrywać należy w kilku wzajemnie skorelowanych czynnikach. Przede wszystkim instytucje edukacyjne realizują model nauki krytykowany przez filozofa jako statyczny i zamknięty na wieloaspektowość rzeczywistości zewnętrznej. W efekcie w miejsce różnorodnej, twórczej aktywności podmiotu poznającego, kształcenie przybiera postać pasywnego przekazywania informacji ujętych w ramy obiektywnych i niepodważalnych twierdzeń narzuconych pod rygorem intelektualnej ignorancji. Co więcej, zunifikowane programy nauczania wykorzystywane w edukacji pomijają aspekt indywidualności, która, w duchu klasycznego liberalizmu filozoficznego, przesądza o kierunku rozwoju młodego człowieka ${ }^{32}$. Zdaniem Feyerabenda, w procesie kształcenia należy jednoznacznie odróżnić proces uczenia się od przygotowania o charakterze zawodowym ${ }^{33}$, w przypadku którego instytucje posiadają uzasadnione prawo do egzekwowania wiedzy i kompe-

${ }^{29}$ Na potwierdzenie czego Feyerabend przytacza kazus starożytnego atomizmu, rewolucji kopernikańskiej czy współczesnych teorii fizycznych. Zob. tamże, s. 23.

${ }^{30}$ Zarówno w aspekcie jej twierdzeń, jak i przydatności samej nauki do objaśniania pewnych klas zjawisk.

${ }^{31}$ Pod pojęciem postawy humanistycznej rozumieć należy nie tyle zawężenie zainteresowań naukowych do dyscyplin o profilu humanistycznym, ile otwartość i swobodę w dokonywaniu reorganizacji zastanego porządku oraz do przyjęcia holistycznej, niewyłącznie naukowej perspektywy oglądu.

32 Przytoczony pogląd wskazuje na silną inspirację Feyerabenda myślą filozoficzną Johna Stuarta Milla. Zob. tamże, s. 20 w zw. z J. S. Mill, O wolności, Warszawa 1959, s. 208.

33 P. K. Feyerabend, Przeciw metodzie, s. 163. 
tencji ograniczonych do konkretnych, podyktowanych celami pragmatycznymi, dziedzin poznania. Z kolei w odniesieniu do edukacji ogólnej ${ }^{34}$,system powszechnego nauczania powinien przygotować obywatela do wyboru pomiędzy zasadami lub do znalezienia swojej drogi [...], lecz w żadnym razie nie można dopuścić do tego, aby naginał jego umysł, dostosowując go do zasad jednej określonej grupy" ${ }^{35}$. Podobnie jak w przypadku uczonych podejmujących aktywność o charakterze naukowym, również w stosunku do młodego pokolenia anarchizm metodologiczny postuluje orientację na twórczy, nieskrępowany rozwój. Co szczególnie istotne, sukces instytucjonalnej działalności edukacyjnej wydaje się wyznaczony nie tyle zasobem opanowanych treści, ile fundamentalną kompetencją do krytycznego, samodzielnego oglądu rzeczywistości zewnętrznej.

Stanowisko Feyerabenda w kwestii roli systemu kształcenia dla rozwoju młodego pokolenia wydaje się zbieżne z podstawowymi intuicjami rozwijanymi w ramach koncepcji liberal education. Elementem odróżniającym edukację liberalną od innych form kształcenia jest jej nieograniczona wymiarem czysto utylitarnym, ponaddyscyplinarna orientacja poznawcza, wsparta rozpoznaniem uzdolnień i zainteresowań (młodego) człowieka. Z wolnością wyboru indywidualnej ścieżki rozwoju koresponduje wolność od wszelkiego rodzaju naukowych, kulturowych, religijnych i metafizycznych indoktrynacji. Nie bez przyczyny idea edukacji liberalnej oparta jest na wysiłku własnym podmiotu poznającego, nie zaś na biernym przekazie informacji, usankcjonowanym tytularnym autorytetem osoby nauczającej ${ }^{36}$. W generalnej perspektywie postulaty Feyerabenda wydają się zbieżne z podstawowym zamysłem edukacji liberalnej, za jaki uznać można realizację potrzeby świadomego i dobrowolnego uczestnictwa w intelektualnym, kulturowym, estetycznym i aksjologicznym dziedzictwie ludzkiej myśli ${ }^{37}$.

$\mathrm{Na}$ wskazanie zasługują związki anarchizmu metodologicznego z klasycznym liberalizmem filozoficznym ${ }^{38}$. Inspiracje Feyerabenda myślą liberalizmu brytyjskiego zauważalne są zwłaszcza w warstwie założeniowej,

${ }^{34}$ Która wydaje się tożsama znaczeniowo z kategorią edukacji liberalnej.

35 Tamże.

${ }^{36}$ Wydaje się, że edukacja liberalna nie wyklucza tradycyjnych form kształcenia, opartych chociażby na herbartowskim modelu nauczania wychowującego. Z drugiej strony, zgodnie z postulatami Feyerabenda, rozwój zakłada indywidualny wysiłek podmiotu poznającego skoncentrowany wokół nabywania wiedzy, umiejętności i postaw wykraczających poza treści przekazywane metodą wyłącznie podawczą.

${ }^{37}$ Por. R. S. Peters, Ethics and Education, London 1970, s. 27 n.

${ }^{38}$ W szczególności w wydaniu Johna Stuarta Milla. 
skoncentrowanej wokół nadrzędnej kategorii wolności. Zgodnie ze stanowiskiem Johna Stuarta Milla, do natury człowieka przynależy możność osiągnięcia postępu rozumianego na sposób głęboko humanistyczny jako doskonalenie w płaszczyźnie moralnej, intelektualnej i praktycznej ${ }^{39}$. Zarazem granice działań wyznacza wolność definiowana negatywnie przez pryzmat dobra osób trzecich. Podobną intuicję odnaleźć można na gruncie systemu Feyerabenda. Jakkolwiek filozof abstrahuje od prób interpretacji pojęcia wolności, jej istnienie niewątpliwie uznaje za warunek konieczny możliwości prowadzenia nieskrępowanej i niezdogmatyzowanej działalności poznawczej. Co więcej, w myśl anarchizmu metodologicznego naturalnie wpisana jest kategoria rozwoju. Cechuje ona poszczególne dyscypliny nauki, ale przede wszystkim podmioty wykazujące aktywność poznawczą. Zarówno w przypadku klasycznego liberalizmu, jak i anarchizmu metodologicznego rozwój pozostaje $\mathrm{w}$ ścisłym związku z własnością indywidualności. Zgodnie ze stanowiskiem Milla, fakt istnienia różnic podmiotowych stanowi, obok wewnętrznej dyscypliny, źródło indywidualnych, a w szerszej perspektywie również wspólnotowych, korzyści optymalizujących społeczne, kulturowe i intelektualne funkcjonowanie człowieka ${ }^{40}$. Pogląd ten zdaje się podzielać Feyerabend, utożsamiający rozwój z indywidualnościąa ${ }^{41}$ Wzajemna niesprowadzalność ścieżek rozwojowych stanowić ma gwarancję pełnego, dobrowolnego i świadomego rozwoju w duchu ideałów humanistycznych.

Poza wskazanymi uprzednio aspektami związanymi z warunkami, celami i istotą edukacji liberalnej, związki pomiędzy anarchizmem filozoficznym i anglosaską koncepcją liberal education zauważalne są również na płaszczyźnie zaleceń kierowanych pod adresem pedagogów i nauczycieli. W opinii Feyerabenda,

postępowi wychowawcy zawsze próbowali rozwinąc indywidualność swoich uczniów i doprowadzić do pełnego rozkwitu szczególne, czasem zupełnie wyjątkowe talenty i przekonania dziecka. [...] Można w pełni zachować to, co bywa nazywane swobodą twórczości artystycznej, nie wykorzystując tej swobody jako drogi ucieczki, ale raczej posługując się nią jako niezbędnym środkiem odkrywania, a może i przekształcania cech świata, w którym żyjemy ${ }^{42}$.

${ }^{39}$ K. Wrońska, Pedagogika klasycznego liberalizmu w dwugłosie John Locke i John Stuart Mill, Kraków 2012, s. 121.

40 Tamże, s. 126.

${ }^{41}$ P. K. Feyerabend, Przeciw metodzie, s. 20.

42 Tamże, s. 44. 
Koncentracja na różnicach będąca fundamentem konstruktywnej działalności edukacyjnej stanowi warunek odkrywania i aktywnego partycypowania w dorobku nauki. Podstawowego znaczenia nabiera przy tym wychowanie do wyboru. Odrzucenie mitu jednomyślności i obiektywności twierdzeń nauki, jak również jej jakościowej przewagi nad alternatywnymi formami poznania umożliwia podjęcie świadomej decyzji w sprawie ustaleń epistemologicznych wyznaczających model myślenia o rzeczywistości zewnętrznej. Należy przy tym podkreślić, że intencją Feyerabenda nie jest dekonstrukcja zastanego porządku, a jedynie zmiana perspektywy, akcentująca pozytywny charakter różnorodności bez równoczesnego wartościowania i podnoszenia roszczeń o obiektywną ważność pewnych arbitralnie wyodrębnionych elementów.

Koncepcja liberal education wydaje się wspierać ideę rozwijania indywidualnych uzdolnień i zainteresowań jako warunku optymalnego rozwoju w sferze intelektualnej, kulturowej czy artystycznej. Utożsamienie procesu zdobywania wiedzy z rozwojem umysłu posiada doniosłe konsekwencje pedagogiczne, w znacznej mierze uzależnia bowiem kształtowanie postawy humanistycznej od działań podejmowanych przez instytucje oświatowe i wychowawcze $^{43}$. O ile w przypadku kształcenia zawodowego ironiczne, lecz do pewnego stopnia uzasadnione, wydaje się operowanie retoryką przedsiębiorstwa wiedzy, o tyle w odniesieniu do edukacji liberalnej wykładnię taką uznać należy za upraszczającą, a ponadto osłabiającą znaczenie wykształcenia humanistycznego ${ }^{44}$. Uznanie edukacji za proces wartościowy i pożądany sprzyja niewątpliwie optymalizacji obranych celów rozwojowych. $\mathrm{Z}$ tego względu $\mathrm{z}$ uwagi na szeroką klasę zjawisk i zagadnień rozwijanych w ramach edukacji liberalnej postulować należy redefinicję kategorii eduka$\mathrm{cji}^{45}$, a w rezultacie zbieżne z postulatem Feyerabenda poszerzenie dyskursu o kształceniu o elementy przekraczające aspekt czysto instrumentalny i utylitarny, podkreślające umocowanie edukacji w systemie kulturowym i historycznym oraz wskazujące na korzyść w postaci optymalnego urzeczywistnienia potencjału jednostki.

${ }^{43}$ Należy przy tym zauważyć, że instytucjonalna działalność szkół nie stanowi w żadnym razie wyłącznej płaszczyzny realizacji idei edukacji liberalnej. Z uwagi jednak na obowiązek szkolny wychowawczo-edukacyjną rolę instytucji oświatowych ocenić należy jako potencjalnie doniosłą.

${ }^{44}$ P. K. Feyerabend, Przeciw metodzie, s. 44.

45 Więcej na temat wykładni pojęcia edukacji zob. R. S. Peters, Education and the Educated Man, ,Journal of Philosophy of Education” 1 (1970), s. 12n. 


\section{Konkluzje}

Przeprowadzone rozważania pozwalają na wyciągnięcie kilku wniosków o charakterze ogólnym. Anarchizm metodologiczny stanowi koncepcję złożoną, wymagającą pogłębionej interpretacji. Jakkolwiek znacząca część poglądów Feyerabenda dotyczących związków filozofii, fizyki, matematyki $i$ astronomii nie posiada bezpośredniego przełożenia na zagadnienia pedagogicznie relewantne, ich analiza dostarcza uzasadnienia na rzecz tezy, zgodnie z którą postulaty anarchistyczne nie wynikają z uproszczonego i naiwnego poglądu na świat. Przeciwnie, są one konsekwencją przyjęcia wyjątkowo szerokiej perspektywy oglądu, przekraczającej wyłącznie naukowy punkt widzenia. Maksyma anything goes przenosi ciężar rozważań na poziom wyższego rzędu w stosunku do tego, na którym ugruntowany został tradycyjny pogląd o istnieniu różnicy jakościowej pomiędzy nauką a pozostałymi sposobami poznania. Feyerabend odrzuca optykę jednej epistemologii, proponując w zamian orientację na różnorodność. Co więcej, filozof znosi mit nauki jako spójnego, zgodnego przedsięwzięcia badaczy, wskazując, że jedynym elementem łączącym niezgodne i niewspółmierne teorie jest ich wspólna nazwa.

Postulaty anarchizmu metodologicznego nie pozostają bez wpływu na problematykę edukacji liberalnej. Jakkolwiek Feyerabend nie posługuje się tym terminem, intuicje dotyczące postawy humanistycznej wydają się w dużym stopniu zbieżne z podstawowymi wyznacznikami myślenia o liberal education. Równocześnie rozważenia wymaga, czy radykalne odrzucenie perspektywy myślenia o nauce nie przekreśla możliwości realizacji ideału liberalnego, świadomego, wszechstronnego rozwoju. Wydaje się, że podstawowe założenia koncepcji liberal education pozostają w związku z filozofią klasycznego liberalizmu, akcentującą wartość płynącą z poznania naukowe$\mathrm{go}^{46}$. Sam fakt powiązania nauki z kształceniem umysłowym i rozwijaniem sprawności rozumu sugeruje jej uprzywilejowaną pozycję względem alternatywnych strategii poznania. Warto zaznaczyć, że przekonanie o jakościowym prymacie nauki stanowi w historii ludzkiej myśli pogląd przeważający, prezentowany radykalnie częściej niż stanowisko opozycyjne. Podstawowa trudność w odnoszeniu filozofii anarchizmu metodologicznego do koncepcji liberal education sprowadza się do wątpliwości, czy bezpardonowe zniesie-

${ }^{46}$ W przypadku XIX-wiecznej filozofii liberalnej rozumianego na sposób empiryczny. Zob. K. Wrońska, Liberal Education... (Period 1), s. 35. 
nie autorytetu nauki w imię epistemologicznej różnorodności nie usuwa poznawczego fundamentu i poczucia pewności gwarantowanej niegdyś przez racjonalną, stabilną wizję nauki.

Wydaje się, że z koncepcją edukacji liberalnej i postawy humanistycznej powiązać należy przeświadczenie o istnieniu zasobu wiedzy, kompetencji, postaw czy przekonań w wyższym stopniu wartych internalizacji niż inne oferowane na gruncie nauki i kultury. Realizacja ideału człowieka wykształconego na sposób liberalny wymaga przyswojenia treści uznanych za szczególnie wartościowe i istotne. W sytuacji równouprawnionej wielości zadanie to ulega komplikacji będącej rezultatem zniesienia kryterium powszechnej ważności, pozwalającego na wartościowanie elementów z uwagi na doniosłość przypisaną $\mathrm{w}$ toku naukowego czy kulturowego postępu. Wolność wyboru z całą pewnością sprzyja twórczemu rozwojowi. Równocześnie za warunek konstytutywny urzeczywistnienia postawy humanistycznej uznać należy świadomość wielości źródeł poznania oraz umiejętność dokonywania krytycznej selekcji dostępnych treści. Kompetencja ta nabywana jest w toku długodystansowej aktywności poznawczej. Jako że próżno szukać jej wśród dzieci i młodzieży, problem praktycznej implementacji maksymy anything goes $\mathrm{w}$ zakres edukacji instytucjonalnej uznać należy za wymagający dalszych, pogłębionych analiz.

System filozoficzny Feyerabenda z całą pewnością zawiera komponenty charakterystyczne dla koncepcji liberal education. Otwarte pozostaje pytanie, czy radykalna interpretacja wolności nie prowadzi do wypaczenia idei edukacji liberalnej. Wydaje się, że rozwój postrzegany z punktu widzenia filozofii liberalnej wolność lokuje po stronie podmiotu poznającego, umożliwiając tym samym dobrowolność kontaktu z przekazami o charakterze naukowym, kulturowym, moralnym czy artystycznym. Warstwa przedmiotowa wydaje się cechować względną stabilnością, co więcej, posiada wyraźną strukturę powstałą na skutek wartościowania uwzględniającego rozmaite kryteria. Jakkolwiek Feyerabend wzbrania się przed rozpatrywaniem swoich postulatów w kategoriach strumienia świadomości zastępującego dotychczasową naukową racjonalność ${ }^{47}$, sądzić można, że wyposażenie jednostki w wolność wyboru przy równoczesnym zniesieniu poznawczych kierunkowskazów w postaci powszechnego przekonania o ważności i istotności pewnych zbiorów twierdzeń doprowadzić może do sytuacji kognitywnej dez-

47 P. K. Feyerabend, Przeciw metodzie, s. 163. 
orientacji ${ }^{48}$. Podobnie jak w przypadku problemu konsekwencji pluralizmu epistemologicznego dla realizacji ideału wykształcenia humanistycznego, zagadnienie granic wolności rozumianej na sposób anarchistyczny wymaga dalszych analiz.

Pomimo radykalnych intuicji stanowisko Feyerabenda uznać można, z zastrzeżeniem wskazanych wątpliwości, za zbieżne z podstawowymi postulatami koncepcji edukacji liberalnej. Pogląd na kwestię kształcenia młodego pokolenia, wyrażający się w odróżnieniu kształcenia liberalnego i zawodowego, jak również akcentowanie ludzkiej indywidualności i twórczej swobody w realizacji zainteresowań poznawczych charakteryzuje myśl klasycznego liberalizmu oraz dwudziestowiecznej filozofii edukacji liberalnej. Ponadto, podobieństw poszukiwać można w odniesieniu do wizji wspomagającej roli nauczyciela, wartości kulturowego i historycznego kontekstu uprawiania nauki czy uznania indywidualnego i wspólnotowego waloru płynącego z odkrywania i twórczego kontynuowania dorobku intelektualnego, kulturowego i artystycznego. Nie ulega wątpliwości, że z uwagi na nowatorskie poglądy filozoficzne stanowisko Feyerabenda w kwestii liberal education wykracza poza ramy dyskursu o edukacji, prowadzonego przez badaczy anglosaskich. Równocześnie anarchizm metodologiczny wspiera tezę o potrzebie zagwarantowania przedmiotowo i podmiotowo rozumianej wolności oraz o konieczności kształtowania krytycznej kompetencji oglądu rzeczywistości zewnętrznej. Wespół z orientacją na indywidualizm i uznaniem ważności wszechstronnego rozwoju człowieka, stanowisko Feyerabenda w wykładni wyznaczonej przez anglosaską filozofię liberal education uznać można za liberalne sui generis, z uwzględnieniem modyfikacji wynikających z przyjęcia optyki pluralizmu epistemologicznego.

\section{Liberal Education Themes in the Philosophy of Methodological Anarchism of Paul K. Feyerabend (Summary)}

The paper aims at analyzing the conception of Austrian philosopher of science, Paul K. Feyerabend, for compatibility with the fundamental determinants of the conception of liberal education. The considerations are centered around attempts to answer the question of whether it is possible to indicate themes characteristic for Anglo-Saxon interpretation of the category of liberal education in the philosophy

48 Stanowisko umiarkowane, krytyczne wobec mitu jednej prawdy i jednego faktu, a zarazem akcentujące racjonalność poznania naukowego, prezentuje Imre Lakatos. Podob- 
of methodological anarchism. The analysis begins with a brief presentation of the philosophical views of Feyerabend, including, in particular, the findings on the role and place of science amongst other ways to achieve knowledge, the idea of epistemological pluralism and the conditions for acceptability of cognitive perspective characteristic for humanities. Further investigations are focused on the conception of liberal education, with particular emphasis on its subjective and objective aspects. Characteristics of abovementioned topics give rise to the analysis of the title problem. The investigations are concluded with an affirmative answer to the question of relationship between methodological anarchism and the conception of liberal education, and indication of issues that require further study.

Keywords: philosophy of education; philosophy of science; liberalism; upbringing; education.

\section{Wątki liberal education w filozofii anarchizmu metodologicznego Paula K. Feyerabenda (Streszczenie)}

Celem artykułu jest analiza koncepcji austriackiego filozofia nauki Paula K. Feyerabenda pod kątem zgodności z podstawowymi wyznacznikami koncepcji liberal education. Rozważania skoncentrowane są wokół próby odpowiedzi na pytanie, czy w filozofii anarchizmu metodologicznego odnaleźć można wątki charakterystyczne dla anglosaskiej wykładni kategorii edukacji liberalnej. Analizę otwiera skrótowa prezentacja filozoficznych poglądów Feyerabenda, obejmująca w szczególności ustalenia dotyczące roli i miejsca nauki pośród innych sposobów osiągania wiedzy, ideę pluralizmu epistemologicznego oraz warunki możliwości przyjęcia humanistycznej perspektywy poznawczej. W dalszej kolejności rozważania skoncentrowane są wokół koncepcji liberal education ze szczególnym uwzględnieniem jej przedmiotowego i podmiotowego aspektu. Charakterystyka wskazanych zagadnień daje asumpt do analizy problemu tytułowego. Dociekania zamyka twierdząca odpowiedź na pytanie o związki anarchizmu metodologicznego z koncepcją liberal education oraz wskazanie zagadnień wymagających dalszego opracowania.

Slowa kluczowe: filozofia edukacji; filozofia nauki; liberalizm; wychowanie; kształcenie.

nie jak Feyerabend, filozof sprzeciwia się instytucjonalnemu uwikłaniu nauki i ograniczeniu wolności działalności naukowej w imię celów społecznych i politycznych. Zarazem jednak, w opozycji do Feyerabenda, uznaje prymat poznania o charakterze naukowym. Zob. I. Lakatos, Społeczna odpowiedzialność nauki, w: tenże, Pisma z filozofii nauk empirycznych, Warszawa 1995, s. 363n. 